\title{
ADENOMIOMA DA PAPILA DE VATER EM ADULTO JOVEM
}

\author{
ADENOMYOMA OF THE PAPILLA OF VATER IN A YOUNG ADULT
}

\author{
Antônio Nocchi Kalil, TCBC-RS ${ }^{1}$ \\ Mário da Cunha Brodt ${ }^{2}$ \\ Eduardo Touguinha Mastalir ${ }^{3}$
}

\section{INTRODUÇÃO}

As neoplasias benignas da papila de Vater (PV) são raras, ${ }^{1-3}$ sendo que os tumores benignos mais comuns dos ductos biliares extra-hepáticos são adenomas, adenomiomas e neoplasias mesenquimais. ${ }^{1} \mathrm{O}$ adenomioma na árvore biliar localiza-se preferencialmente no fundo da vesícula, sendo raro na PV. ${ }^{2} \mathrm{~A}$ possibilidade de tratar com sucesso uma paciente com adenomioma desta localização motivou o presente relato.

\section{RELATO DO CASO}

Uma jovem de 18 anos com episódios de cólica biliar nos últimos três anos apresentou há três meses quadro de prurido intenso, icterícia flutuante, colúria, acolia, diarréia, inapetência, dispepsia e emagrecimento $(10 \mathrm{~kg}$ em três meses). Procurou auxílio médico por dor abdominal intensa, sendo evidenciado sinal de Courvoisier, além dos sinais e sintomas apresentados anteriormente. Os exames laboratoriais durante a internação foram aspartatoaminotransferase (TGO) $87 \mathrm{U} / \mathrm{L}$, alanina-aminotransferase (TGP) $53 \mathrm{U} / \mathrm{L}$, bilirrubina total $26 \mathrm{mg} / \mathrm{dL}$, bilirrubina direta $21,4 \mathrm{mg} / \mathrm{dL}$, gama-glutamiltransferase (G-GT) 247 U/L, amilase $37 \mathrm{U} / \mathrm{L}$ e lipase $84 \mathrm{U} / \mathrm{L}$. A ecografia (ECO) e a tomografia abdominal (TC) demonstraram ausência de cálculos biliares, obstrução e dilatação coledociana de 1,7 $\mathrm{cm}$. Colangiografia intra-operatória (Figura 1) mostrou dilatação das vias biliares e à palpação constatou-se dilatação do colédoco, massa periampular pétrea com $2 \mathrm{~cm}$ de extensão, sugerindo neoplasia maligna da PV, realizando-se uma gastroduodenopancreatectomia cefálica (GDPT).

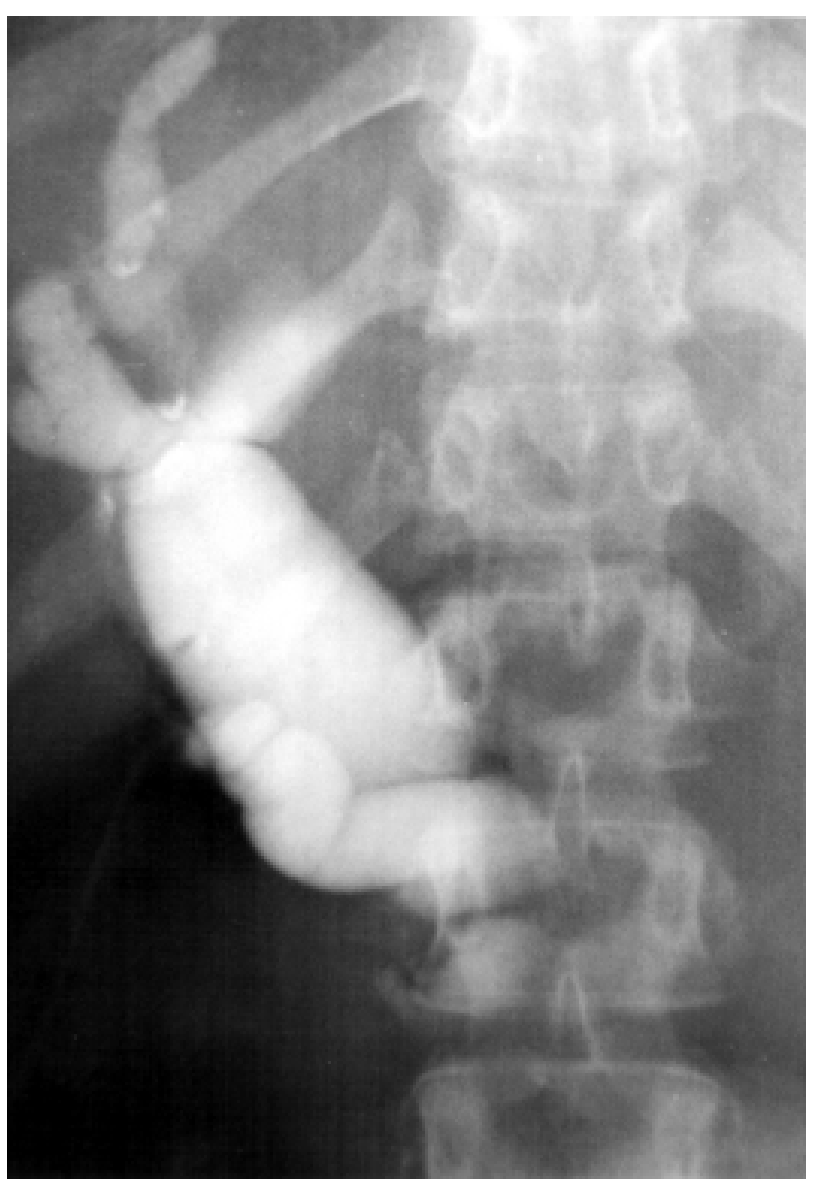

Figura 1 - Colangiografia intra-operatória, demonstrando dilatação da via biliar e ausência de passagem do contraste para o duodeno.

1. Professor Adjunto-Doutor do Departamento de Cirurgia e Coordenador do Curso de Pós-Graduação em Clínica Cirúrgica da FFFCMPA.

2. Acadêmico de Medicina e Doutorando da FFFCMPA.

3. Acadêmico de Medicina da FFFCMPA e Bolsista do CNPq.

Recebido em 7/6/99

Aceito para publicação em 17/11/99

Trabalho realizado no Departamento de Cirurgia da Fundação Faculdade Federal de Ciências Médicas de Porto Alegre (FFFCMPA) e Complexo Hospitalar Santa Casa de Porto Alegre. 
A paciente teve alta hospitalar no décimo terceiro dia pós-operatório com diagnóstico histológico de adenomioma da PV (Figura 2). Estudo imuno-histoquímico da PV revelou positividade para vimentina e actina muscular nas células fusiformes constituintes do estroma. Além disso, o estudo do Anti-Human C-kit, CD117 demonstrou negatividade para tumor de células estromais (neoplasia não-epitelial do intestino delgado). Três meses após o procedimento a doente encontra-se assintomática.

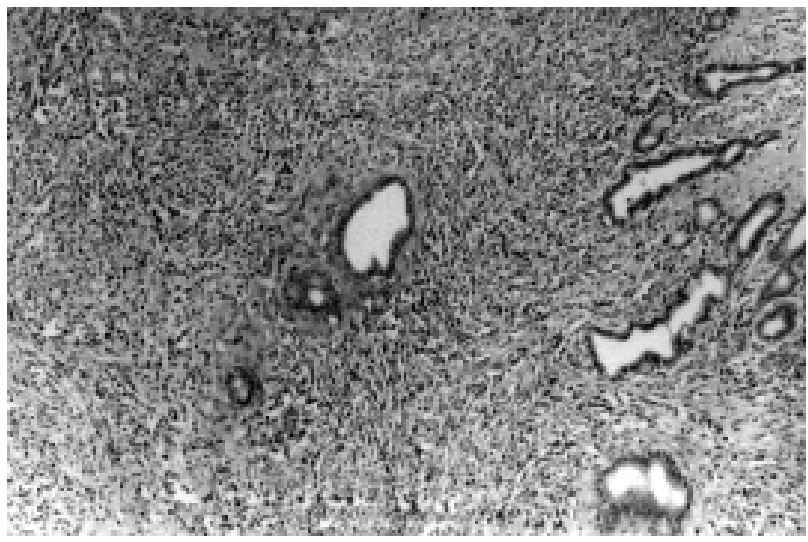

Figura 2 - Exame histológico da papila de Vater (HE - 100x). Vêem-se glândulas de tamanho variável, por vezes comprimidas, em meio a estroma constituído por células fusiformes (miofibroblástico). Seu caráter benigno fica evidenciado pelas raras mitoses encontradas.

\section{DISCUSSÃO}

Normalmente, os adenomiomas da PV são encontrados em mulheres acima de 50 anos, ${ }^{1-3}$ e a confirmação diagnóstica pré-operatória é muito difícil. ${ }^{2}$ Os achados clínicos habitualmente encontrados são dor abdominal, dispepsia e, mais freqüentemente, icterícia. ${ }^{2}$ No presente caso, a paciente apresentava cólica biliar por um longo período, dispepsia de início recente e icterícia tipicamente colestática.

Em relação ao diagnóstico por imagem, ECO, TC e colangiografia não excluem tumor maligno ${ }^{2}$, podendo ser útil neste sentido a biópsia por via endoscópica. ${ }^{2,3}$ No presente caso, a ECO e a TC apenas demonstraram obstrução do colédoco distal e dilatação das vias biliares a montante da lesão, sendo sua natureza benigna evidenciada pelo exame histológico da peça operatória.

Não existe consenso na literatura em relação ao tratamento do adenomioma da PV, embora Burhans e Myers ${ }^{4}$ tenham demonstrado recidiva maior $(22 \%)$ com ressecção local e mortalidade operatória similar entre ressecção tumoral local e extensa ( $8 \%$ e $11 \%$, respectivamente), ainda que dados de diferentes centros demonstrem mortalidade inferior a 5\% para a GDPT. ${ }^{5}$ Neste caso, devido à extensão e ao aspecto da lesão, optou-se pela ressecção através de GDPT.

Desta forma, enfatizamos a necessidade de inclusão desta patologia rara no diagnóstico diferencial de pacientes ictéricos, especialmente nesta faixa etária e com as características clínicas apresentadas. O tratamento de escolha deve ser a ressecção da lesão, preferencialmente pela GDPT, dada a possibilidade de recidiva com ressecção local e dificuldade de estabelecer sua natureza benigna pelos exames de imagem e exploração cirúrgica.

\begin{abstract}
The authors report a case of adenomyoma of papilla of Vater in a young adult, a rare pathology in this age and site. The commonest clinical findings are abdominal pain, dyspepsia and jaundice, as in this case in which the patient referred these symptoms for several months. The diagnosis is usually difficult before surgery, because the radiological and endoscopic appearances are difficult to interpret, since they may only show obstruction and enlargement of the biliary tract; in this way, the endoscopic biopsy may be useful. In the present case the computed tomography, abdominal scan and intraoperative cholangiography only demonstrated obstruction and enlargement of the biliary tract, without the presence of gallstones. The treatment is usually lesion resection according to its size, performing the total resection in those cases of extensive involvement of the digestive tract, as it was performed in this case, due to the dimension of the lesion and its malignant appearance. The patient was discharged from hospital on the thirteenth postoperative day, with a histological diagnosis of adenomyoma of papilla of Vater. Three months after the procedure the patient was asymptomatic.
\end{abstract}

Key Words: Adenomyoma; Papilla of Vater; Biliary obstruction.

\section{REFERÊNCIAS}

1. Ulich TR, Kollin M, Simmons GE et al. - Adenomyoma of the papilla of Vater. Arch Pathol Lab Med 1987; 111: 388-90.

2. Ligorred L, Morollón MJ, Aragón J et al. - Obstructive jaundice from an adenomyoma of the ampulla of Vater. Rev Esp Enferm Dig 1997; 89(5):411-2.

3. Hammarström LE, Holmin T, Stenram U - Adenomyoma of the ampulla of Vater: an uncommon cause of bile duct obstruction. Surg Laparosc Endosc 1997; 5: 388-93.
4. Burhans R, Myers RT - Benign neoplasms of the extrahepatic biliary ducts. Am Surg 1971; 37: 161-6.

5. Bottger TC, Junginger T - Factors Influencing morbidity and mortality after pancreaticoduodenectomy: critical analysis of 221 resections. World J Surg 1999; 23 (2): 164-71.

\section{ENDEREÇO PARA CORRESPONDÊNCIA}

Dr. Antônio Nocchi Kalil

Rua Marcelo Gama, 924 - 2o andar

90540-041 - Porto Alegre - RS 